\title{
Feeding preference of adult females of ribbonfish Trichiurus lepturus through prey proximate-composition and caloric values
}

\author{
Vanessa Trindade Bittar ${ }^{1}$, Danielle Rodrigues Awabdi ${ }^{1}$, William Cristiane Teles Tonini ${ }^{3}$, \\ Manuel Vazquez Vidal Junior ${ }^{2}$ and Ana Paula Madeira Di Beneditto ${ }^{1}$
}

In the present study we analysed the proximate-composition and caloric values of the preferred prey consumed by ribbonfish, Trichiurus lepturus L. 1758 (adult females), that are distributed in the inner continental shelf from northern Rio de Janeiro State, southeastern Brazil $\left(\sim 22^{\circ} \mathrm{S}\right)$, assessing the potential of nutritional and energetic approach as a tool to understand the feeding selective pattern of this marine top carnivore. The preferred prey of this predator composed of fish co-specifics, Pellona harroweri, Chirocentrodon bleekerianus, Lycengraulis grossidens, Peprilus paru, squid Doryteuthis plei, and shrimp Xiphopenaeus kroyeri were collected from 2007 to 2010 for proximate-composition (water, protein, lipid, ash, and carbohydrate) and caloric value analyses. The correspondence analysis showed that protein is the main component in the prey species (61.32\% of variance explained), standing out from the other nutrients. Lipid has the highest percentage related to L. grossidens, ash to X. kroyeri and carbohydrate to D. plei. The strong correlations between protein and caloric value (positive) and lipid and caloric value (negative) indicated that T. lepturus is attending its energy demand through the prey protein content. This work elucidated the feeding preference of adult females of T. lepturus in relation to nutritional and caloric content of their preferred prey. The species showed food selectivity to prey that provide more energy per ingested biomass, so that the feeding events can maximize the predator's caloric gain, which is obtained by a protein-based diet.

No presente estudo foram analisadas a composição centesimal e o valor calórico das presas preferenciais consumidas pelo peixeespada, Trichiurus lepturus L. 1758 (fêmeas adultas), que se distribuem na plataforma continental interna do norte do estado do Rio de Janeiro, sudeste do Brasil $\left(\sim 22^{\circ} \mathrm{S}\right)$. O objetivo foi avaliar o potencial da abordagem nutricional e energética como ferramenta para compreender o padrão de seletividade alimentar deste carnívoro marinho. As presas preferenciais deste predador, compostas por co-específicos e pelos peixes Pellona harroweri, Chirocentrodon bleekerianus, Lycengraulis grossidens e Peprilus paru, pela lula Doryteuthis plei e pelo camarão Xiphopenaeus kroyeri, foram coletadas entre 2007 e 2010 para análise da composição centesimal (água, proteína, lipídio, cinzas e carboidratos) e do valor calórico. A análise de correspondência mostrou que a proteína é o principal componente nas espécies de presa (61,32\% da variância explicada), destacando-se dos outros nutrientes. Para o lipídio a maior porcentagem esteve relacionada com L. grossidens, cinzas com X. kroyeri e carboidratos com D. plei. As fortes correlações entre proteína e valor calórico (positiva) e lipídio e valor calórico (negativa) indicaram que $T$. lepturus está atendendo sua demanda de energia através do teor de proteína das presas. Este trabalho elucidou a preferência alimentar de fêmeas adultas de T. lepturus em relação ao conteúdo nutricional e calórico das presas preferenciais. A espécie apresentou seletividade alimentar por presas que fornecem mais energia por biomassa ingerida, de modo que os eventos de alimentação maximizem o ganho calórico do predador, que é obtido por uma dieta à base de proteínas.

Key words: Feeding, Marine fish, Prey composition, Seafood, Trichiuridae.

\footnotetext{
${ }^{1}$ Universidade Estadual do Norte Fluminense Darcy Ribeiro (UENF), Programa de Pós-Graduação em Ecologia e Recursos Naturais, Laboratório de Ciências Ambientais, Centro de Biociências e Biotecnologia, Avenida Alberto Lamego, 2000, 28013-620 Campos dos Goytacazes, RJ, Brazil. vatrindade@gmail.com

${ }^{2}$ Universidade Estadual do Norte Fluminense Darcy Ribeiro (UENF), Centro de Ciências e Tecnologias Agropecuárias, Laboratório de Zootecnia e Nutrição Animal, Avenida Alberto Lamego, 2.000, 28013-620 Campos dos Goytacazes, RJ, Brazil.

${ }^{3}$ Universidade Estadual de Santa Cruz, Laboratório de Nutrição de Organismos Aquáticos, Campus Soane Nazaré de Andrade, km 16 Rodovia Ilhéus-Itabuna, 45662-900 lhéus, Bahia, Brazil.
} 


\section{Introduction}

The nutritional and energetic approaches complement traditional studies on feeding habits in animals, such as stomach content analysis (e.g. Murie \& Lavigne, 1986; Di Beneditto et al., 2001; Martins et al., 2005; Bittar \& Di Beneditto, 2009), especially when ecological characteristics of target species are joined with biochemical components such as proteins and lipids (Eder \& Lewis, 2005). Although the number of studies utilising this approach is still limited, in recent years there has been an increasing interest in this topic (e.g. Arnould et al., 2005; Eder \& Lewis, 2005; Doyle et al., 2007; Gauquelin et al., 2007; Tang et al., 2007; Di Beneditto et al., 2009; Spitz et al., 2010; Hossain et al., 2011).

The energy density and proximate-composition are associated with interspecific characteristic environmental conditions (Clarke et al., 1994; Payne et al., 1999; Tierney et al., 2002; Eder \& Lewis, 2005; Yan et al., 2011), and influence the dynamics of marine trophic webs. Current knowledge regarding the energy and nutritional composition of organisms allows assessment of energy transference rates among trophic levels (Eder \& Lewis, 2005), understanding population dynamics and predators feeding behavior (Benoit-Bird, 2004) and bioenergetic modeling (Tierney et al., 2002). This approach becomes more important in studies of marine organisms, where in situ observation is difficult or cannot be practiced due to environmental conditions (Benoit-Bird, 2004).

The ribbonfish, Trichiurus lepturus L. 1758, is a marine carnivorous fish found worldwide in tropical and subtropical regions, and is an important fishery resource (FAO, 2005). This species can switch between estuarine and marine ecosystems, including coastal and oceanic areas, according to its life cycle stage and food demand (Elliot et al., 2007). During the ontogeny, the species change their feeding habits being zooplanktivore feeder at juvenile stage $(5-30 \mathrm{~cm}$ length), and becoming a voracious carnivore when adult (more than $100 \mathrm{~cm}$ length), feeding mainly on pelagic and demersal fishes, including co-specifics, which characterized the cannibalism behavior (e.g. Nakamura \& Parin, 1993; Martins et al., 2005; Chiou et al., 2006; Bittar \& Di Beneditto, 2009; Yan et al., 2011). Although the feeding ecology of this species has been studied through many approaches (e.g. Wojciechowski, 1972; Martins et al., 1997; Martins et al., 2005; Chiou et al., 2006; Bakhoum, 2007; Bittar et al., 2008; Al-Nahdi et al., 2009; Bittar \& Di Beneditto, 2009; Yan et al., 2010; Yan et al., 2011), there is no available information on nutrition and energetics of its.

The present study analysed the proximate-composition and caloric value of the preferred prey consumed by adult female ribbonfish that are distributed along the inner continental shelf of northern Rio de Janeiro state, southeastern Brazil $\left(\sim 22^{\circ} \mathrm{S}\right)$. The goal was assess the potential of nutritional and energetic approach as a tool to understand the selective feeding pattern of this marine top carnivore and testing the hypothesis that adult fish prefer prey with higher caloric value to attend their energy demand. As this fish shares the prey species with other carnivores in this region (Di Beneditto \& Ramos, 2004; Bittar \& Di Beneditto, 2009), the results may also be applied to better understand the prey consumption of sympatric predators in this region.

\section{Material and Methods}

Sampling. The study area comprehends the north coast of the

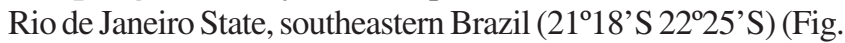
1). The coastline is influenced by the two major river runoffs of the Rio de Janeiro State (Itabapoana and Paraíba do Sul Rivers), and in the south of São Tomé Cape (22 $00^{\circ}$ 'S) there is influence of the Central Water of South Atlantic (CWSA) up-welling from January to March (Muehe \& Valentini, 1998). In northern Rio de Janeiro State the seasons can be grouped into dry (AprilSeptember) and rainy (October-March), which are characterized by lowest and highest values of temperature and rainfall, respectively (Martins et al., 1998). In this region the gillnet fisheries, whose one of the main targets is the species $T$. lepturus, are practice in coastal waters from 1 to 30 nautical miles, up to $50 \mathrm{~m}$ depth (Fig. 1).

The feeding habit of T. lepturus in this region was described in detail by Bittar et al. (2008), investigating adult female specimens (100-163 cm length) captured in commercial gillnet fisheries from 2004 to 2006. In that study, the visual analyses of the ovaries during the fish dissection indicated specimens at various maturity stages. However, the ovaries were not weighted

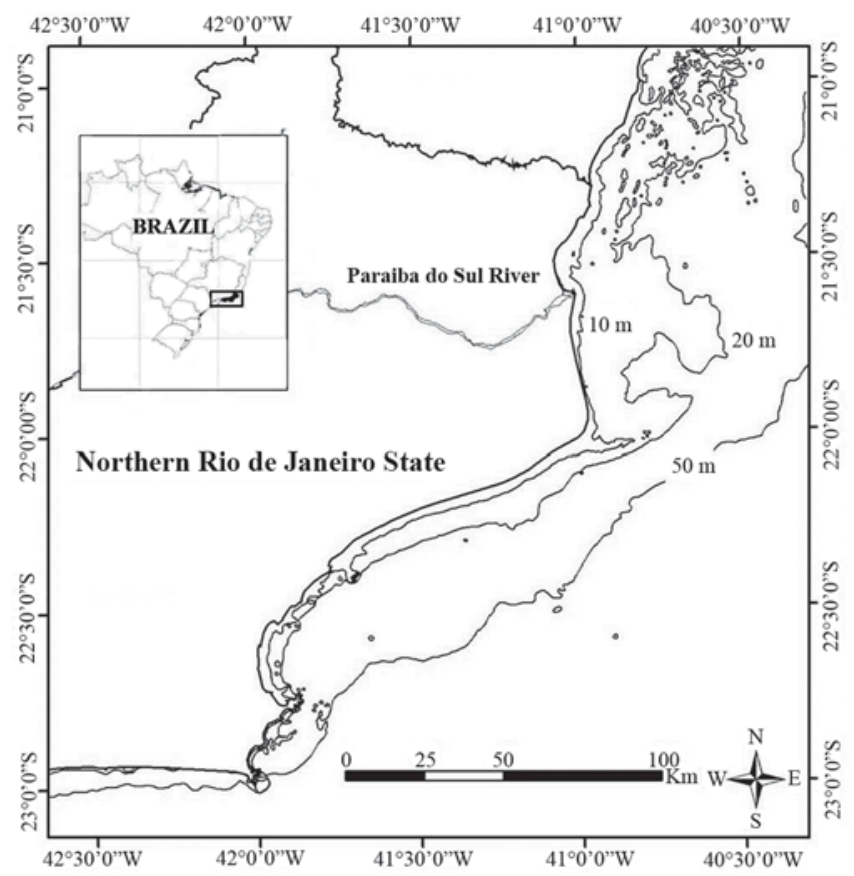

Fig. 1. Map of Brazil with Rio de Janeiro State and its northern coast, where adult female specimens of Trichiurus lepturus and their prey species were collected $\left(21^{\circ} 18^{\prime} \mathrm{S}-22^{\circ} 25^{\prime} \mathrm{S}\right.$; until $50 \mathrm{~m}$ depth). 
Table 1. Sample size, index of relative importance (IRI), total length (cm) and weight ( $\mathrm{g}$ ) of the prey species of Trichiurus lepturus in northern Rio de Janeiro State, Brazil, to proximate-composition and caloric value analysis. $\mathrm{N}=$ number of specimens for the composite samples, ${ }^{\text {a }}$ mantle length.

\begin{tabular}{|c|c|c|c|c|c|}
\hline Prey species & Number of samples & IRI & Total IRI (\%) & $\begin{array}{c}\text { Length } \\
\text { Min-Max (Mean } \pm \text { SD) }\end{array}$ & $\begin{array}{c}\text { Weight } \\
\text { Min-Max (Mean } \pm \text { SD) }\end{array}$ \\
\hline Trichiurus lepturus $(\mathrm{N}=22)$ & 22 & 150 & 33 & $33.9-72.8(45.8 \pm 10.8)$ & $20.1-181.7(58.2 \pm 44.0)$ \\
\hline Pellona harroweri $(\mathrm{N}=185)$ & 28 & 76 & 17 & $9.2-13.8(11.1 \pm 1.2)$ & $7.6-26.8(14.0 \pm 5.3)$ \\
\hline Doryteuthis plei $(\mathrm{N}=15)$ & 3 & 57 & 13 & $3.5-5.8^{\mathrm{a}}(4.2 \pm 1.2)$ & $3.5-18.6(11.0 \pm 7.6)$ \\
\hline Chirocentrodon bleekerianus $(\mathrm{N}=270)$ & 26 & 48 & 11 & $9.4-11.1(10.5 \pm 0.4)$ & $5.2-8.5(6.8 \pm 0.9)$ \\
\hline Xiphopenaeus kroyeri $(\mathrm{N}=183)$ & 12 & 48 & 11 & $2.9-11.0(7.6 \pm 1.9)$ & $1.7-8.9(3.4 \pm 0.7)$ \\
\hline Lycengraulis grossidens $(\mathrm{N}=283)$ & 24 & 27 & 6 & $9.3-14.4(11.9 \pm 1.3)$ & $12.2-24.4(17.5 \pm 3.0)$ \\
\hline Peprilus paru $(\mathrm{N}=74)$ & 13 & 15 & 3 & $9.3-12.5(11.2 \pm 1.1)$ & $11.7-30.6(23.6 \pm 6.5)$ \\
\hline
\end{tabular}

and nor evaluated in relation to maturity stage of oocytes, preventing an accurate analysis of the specimens' maturity. In this previous study, 10 to 17 ribbonfish stomach contents were monthly collected, totalling 350 specimens, and analysed to identify prey species and estimate their original size. The index of relative importance (IRI) of each prey was calculated by $[(\% \mathrm{NF}+\% \mathrm{~B}) \mathrm{x} \% \mathrm{OF}]$, modified to Pinkas et al. $(1971)$, where $\mathrm{NF}=$ numeric frequency, $\mathrm{B}=$ biomass, and $\mathrm{OF}=$ occurrence frequency, considering fish, squids, and shrimps as independent prey. The IRI was recalculated combining all prey species, and those representing around $94 \%$ of the total IRI were selected. (Table 1).

For the proximate-composition and caloric value analyses, the known prey species were collected along the study area from 2007 to 2010 by trawl nets, during commercial captures of shrimp and Sciaenidae fish species, taking into account the preferential sizes consumed and sampling during all seasons. Bittar et al. (2008) reported that the shrimp Pleoticus muelleri (Penaeoidea) was the most important crustacean eaten by $T$. lepturus. However, during the sampling this species was not collected in sufficient mass for analysis, and we decided to replace it with Xiphopenaeus kroyeri (Penaeoidea), which was also found in stomach contents of the predator.

Each individual was measured (total length in $\mathrm{cm}$ ) and weighed (g) after sampling. Specimens with similar size were grouped to form composite samples ( 5 to 11 specimens of each species) to obtain sufficient mass for analysis, and only the co-specifics were considered individually (Table 1). Each sample (whole fresh specimens) was homogenized, frozen and lyophilised (Table 1). In the fish and squid species the scales and mandibles/gladius, respectively, were extracted prior the homogenization.

Proximate-composition and caloric value analysis. The water and ash contents were determined gravimetrically by desiccation at $105^{\circ} \mathrm{C}$ and incineration in an oven at $600^{\circ} \mathrm{C}$, respectively (Horwitz, 1960; A.O.A.C., 1984). The crude protein was obtained by Kjeldahl method (Cunniff, 1998) and the protein content by calculation of the Kjeldahl nitrogen $\mathrm{x}$ 6.25. The lipids were extracted using Folch et al. (1957) method and its content was determined gravimetrically. The protein, lipid and ash content values were expressed as dry mass percentage. All samples were analysed in triplicate. The percentage of carbohydrates was estimate by the relation: $\mathrm{C}$ $=100-(\% \mathrm{P}+\% \mathrm{~L}+\% \mathrm{~A})$, where $\mathrm{C}$ is carbohydrate, $\mathrm{P}$ is protein, L is lipid and A is ash (A.O.A.C., 1984).

We did not have a bomb calorimeter to determine the caloric value $(\mathrm{CV})$ of the prey species, which was indirectly determined through Rubner's coefficient considering $5.65 \mathrm{kcal} \mathrm{g}^{-1}$ to protein, $4.10 \mathrm{kcal} \mathrm{g}^{-1}$ to carbohydrate and $9.45 \mathrm{kcal} \mathrm{g}^{-1}$ to lipid (Winberg, 1971): $\mathrm{CV}=(5.65 * \mathrm{P}+4.10 * \mathrm{C}+9.45 * \mathrm{~L}) / 100$. The caloric value (CV) was express as kcal g ${ }^{-1}$ dry mass. The Rubner's coefficient has been successfully used to estimate the caloric value of fish and other marine organisms, as demonstrated by Eder \& Lewis (2005) and Nurnadia et al. (2011).

Data analysis. Multivariate correspondence analysis was applied to evaluate the association among species and percentages of nutritional components - protein, lipid, ash, and carbohydrate (Ludwig \& Reynolds, 1988; Hair et al. 1999; Eder \& Lewis, 2005). After verifying the assumptions of normality and homoscedasticity, the analysis of variance was conducted by ANOVA, followed by a post hoc Unequal $\mathrm{N}$ Tukey's HSD test, in order to define differences in length, weight, protein, lipid, ash, carbohydrate, and caloric value among the seven prey species. The Pearson correlation was used to test correlations between protein, lipid, ash, carbohydrate and caloric value, taking all prey species into account. Statistical analyses were performed using Statistica 8.0 for Windows (StatSoft, Inc 2007, USA); a value (P) equal to or less than 0.05 indicated statistical significance.

\section{Results}

Protein, the main proximate-composition fraction, presented values ranging from 60 to $73 \%$ in prey species (dry mass). Despite their low percentages, lipids, and carbohydrates varied widely among prey species. The mean energy values ranged between 314 and $500 \mathrm{kcal}_{\text {. }} \mathrm{g}^{-1}$ (dry mass) (Table 2). The highest percentages of protein and energy were related to D. plei, followed by T. lepturus and C. bleekerianus (Table 2). Trichiurus lepturus prey showed the highest IRI (Table 1).

The correspondence analysis showed that protein was 
Table 2. Characterization of the prey species of Trichiurus lepturus in northern Rio de Janeiro State, Brazil, regarding proximatecomposition (\% dry mass) and caloric value ( $\mathrm{kcal} \mathrm{g}^{-1}$ dry mass). $\mathrm{NC}=$ no calculated.

\begin{tabular}{|c|c|c|c|c|c|c|}
\hline Prey species & $\begin{array}{c}\text { Humidity } \\
\text { Min-Max } \\
(\text { Mean } \pm \text { SD) }\end{array}$ & $\begin{array}{c}\text { Protein } \\
\text { Min-Max } \\
(\text { Mean } \pm \text { SD })\end{array}$ & $\begin{array}{c}\text { Lipid } \\
\text { Min-M ax } \\
(\mathrm{M} \text { ean } \pm \text { SD) }\end{array}$ & $\begin{array}{c}\text { Ash } \\
\text { Min-Max } \\
(\text { Mean } \pm \text { SD) }\end{array}$ & $\begin{array}{c}\text { Carbohydrate } \\
\text { Min-Max } \\
(\text { Mean } \pm \text { SD) }\end{array}$ & $\begin{array}{c}\text { Caloric value } \\
\text { Min-Max } \\
(\text { Mean } \pm \text { SD })\end{array}$ \\
\hline Trich iurus lepturus & $\begin{array}{c}63.8-70.4 \\
(67.7 \pm 2.9)\end{array}$ & $\begin{array}{l}53.4-78.4 \\
(68.8 \pm 5.5)\end{array}$ & $\begin{array}{c}2.0-51.9 \\
(12.6 \pm 12.4)\end{array}$ & $\begin{array}{c}6.2-15.1 \\
(11.6 \pm 2.0)\end{array}$ & $\begin{array}{c}0.8-22.2 \\
(14.4 \pm 9.4)\end{array}$ & $\begin{array}{c}317.3-462.2 \\
(414.9 \pm 35.3)\end{array}$ \\
\hline Pellona har roweri & $\begin{array}{l}48.6-73.5 \\
(66.0 \pm 7.5)\end{array}$ & $\begin{array}{l}49.1-69.1 \\
(59.9 \pm 4.3)\end{array}$ & $\begin{array}{c}2.8-27.9 \\
(14.9 \pm 6.8)\end{array}$ & $\begin{array}{c}4.1-18.7 \\
(14.1 \pm 2.9)\end{array}$ & $\begin{array}{c}1.4-23.7 \\
(14.1 \pm 6.6)\end{array}$ & $\begin{array}{c}362.1-430.9 \\
(393.6 \pm 27.0)\end{array}$ \\
\hline Dorytheutis plei & $\begin{array}{c}77.8-79.2 \\
(78.4 \pm 0.7)\end{array}$ & $\begin{array}{c}70.4-74.1 \\
(72.7 \pm 2.0)\end{array}$ & $\begin{array}{l}3.6-10.9 \\
(3.3 \pm 0.2)\end{array}$ & $\begin{array}{c}1.6-2.4 \\
(2.0 \pm 0.4)\end{array}$ & $\begin{array}{c}20.4-24.4 \\
(22.0 \pm 2.2)\end{array}$ & $\begin{array}{c}498.3-502.4 \\
(501.1 \pm 2.4)\end{array}$ \\
\hline Chirocentrodon bleekerianus & $\begin{array}{c}68.2-69.2 \\
(68.7 \pm 0.7)\end{array}$ & $\begin{array}{l}59.4-71.7 \\
(66.1 \pm 2.6)\end{array}$ & $\begin{array}{c}15-16.1 \\
(5.9 \pm 4.3)\end{array}$ & $\begin{array}{c}11.7-21.2 \\
(15.3 \pm 2.1)\end{array}$ & $\begin{array}{c}0.8-19.6 \\
(13.3 \pm 4.8)\end{array}$ & $\begin{array}{c}397.1-451.4 \\
(428.6 \pm 16.9)\end{array}$ \\
\hline Xiphopenaeus kroyeri & $\mathrm{NC}$ & $\begin{array}{l}58.0-65.8 \\
(61.6 \pm 2.5)\end{array}$ & $\begin{array}{l}3.6-10.9 \\
(7.3 \pm 2.4)\end{array}$ & $\begin{array}{c}15.0-19.0 \\
(17.4 \pm 1.3)\end{array}$ & $\begin{array}{c}7.2-19.3 \\
(13.7 \pm 3.7)\end{array}$ & $\begin{array}{c}391.4-436.2 \\
(313.7 \pm 12.6)\end{array}$ \\
\hline Lycengraul is grossidens & $\begin{array}{c}61.8-84.8 \\
(67.4 \pm 7.6)\end{array}$ & $\begin{array}{l}31.5-56.6 \\
(50.8 \pm 6.1)\end{array}$ & $\begin{array}{c}10.3-46.1 \\
(26.7 \pm 11.1)\end{array}$ & $\begin{array}{c}4.3-12.5 \\
(7.9 \pm 2.3)\end{array}$ & $\begin{array}{c}0.7-30.1 \\
(17.0 \pm 10.5)\end{array}$ & $\begin{array}{c}305.1-414.8 \\
(353.3 \pm 43.9)\end{array}$ \\
\hline Peprilus paru & $\begin{array}{c}8.6-11.6 \\
(66.0 \pm 2.0)\end{array}$ & $\begin{array}{l}56.1-71.0 \\
(61.1 \pm 4.7)\end{array}$ & $\begin{array}{c}4.2-43.6 \\
(19.5 \pm 14.1)\end{array}$ & $\begin{array}{c}8.8-14.0 \\
(9.2 \pm 4.4)\end{array}$ & $\begin{array}{c}9.8-24.0 \\
(16.6 \pm 4.9)\end{array}$ & $\begin{array}{c}379.7-422.5 \\
(383.8 \pm 49.3)\end{array}$ \\
\hline
\end{tabular}

the main component in the prey species $(61.32 \%$ of variance explained), standing out from the other nutrients. Lipid had the highest percentage related to L. grossidens, ash to $X$. kroyeri and carbohydrate to D. plei (Fig. 2).

The studied species were significantly different in proximate-composition, except in relation to carbohydrate (Table 3). The interspecific comparison through Tukey test indicated that $T$. lepturus differed from the other prey in relation to size (length and weight), being the largest prey species. Protein and caloric values of the squid D. ple $i$ were significantly higher when compared with other prey. The fish L. grossidens presented lower protein percentages, but higher lipids (Table 3).

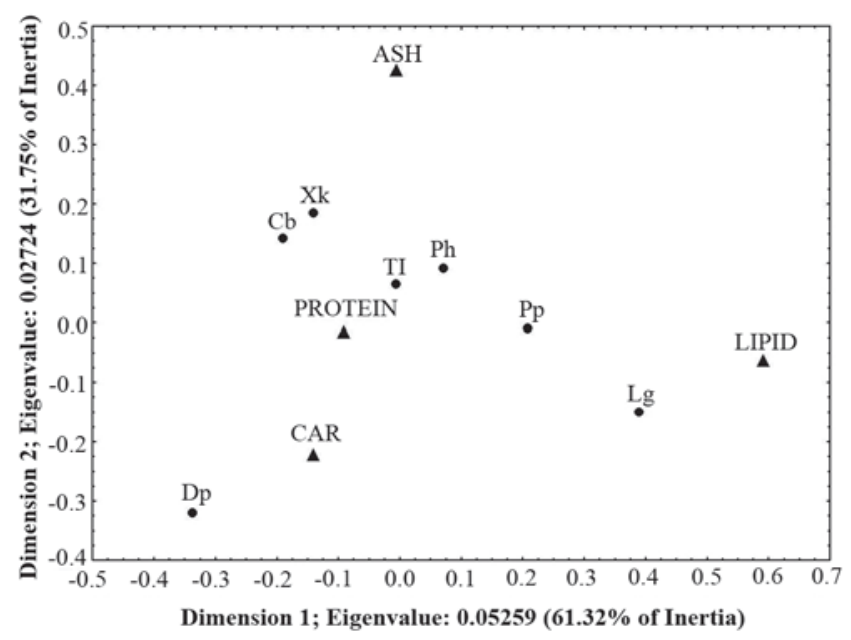

Fig. 2. Multivariate correspondence analysis considering the proximate-composition and prey species of Trichiurus lepturus in northern Rio de Janeiro State, Brazil. Cb: Chirocentrodon bleekerianus; Dp: Doryteuthis plei; Lg: Lycengraulis grossidens; $\mathrm{Ph}$ : Pellona harroweri; Pp: Peprilus paru; Tl: Trichiurus lepturus and Xk: Xiphopenaeus kroyeri. $\mathrm{CAR}=$ carbohydrate.
Considering T. lepturus prey species, there were significant correlations between variables of the proximate-composition. The percentage of protein was directly proportional to the caloric value, while the percentage of lipids showed an inverse relationship with these two variables (Table 4).

\section{Discussion}

The squid D. plei, the co-specifics and the fish $C$. bleekerianus, representing $57 \%$ of the total IRI in the T. lepturus diet, provided the highest average percentage of protein (and caloric content). A basic protein diet was expected in a carnivorous species (Schmidt-Nielsen, 1996), such adult specimens of T. lepturus. Differences in co-occurring prey species regarding proximate-composition and caloric content can be reflecting differences in body structure, life cycle stage, reproductive state, stomach repletion and also of the season (Perez, 1994; Kastelein et al., 2002). In general, it was expected that the caloric intake from squids was low in comparison with fish (Cox et al., 1996; Walker, 1996). However, some authors have detected no difference or specific trend in caloric ingestion when comparing fish, shrimps, and squids as prey species (Perez, 1994; Benoit-Bird, 2004). Di Beneditto et al. (2009) compared information about proximate-composition and caloric value of the prey species consumed by the coastal dolphins Sotalia guianensis and Pontoporia blainvillei, which are sympatric with T. lepturus in northern Rio de Janeiro State (Bittar \& Di Beneditto, 2009), and verified that the squids $D$. plei and D. sanpaulensis provided higher energy content for both dolphins than the fish species. This corroborates our results and indicates that in the study region the coastal squids' components of food webs are more caloric than fish.

All prey species of this top carnivore are abundant year round in northern Rio de Janeiro State (Di Beneditto et al., 2001; Awabdi et al., 2011; Froese \& Pauly, 2011). Adult specimens of $T$. lepturus, both males and females, are considered opportunistic feeders, and the presence of co- 
Table 3. Analysis of variance considering preys' size (length and weight), proximate-composition (\% dry mass) and caloric value ( $\mathrm{kcal} \mathrm{g}^{-1}$ dry mass) of the prey species of Trichiurus lepturus in northern Rio de Janeiro State, Brazil. Cb: Chirocentrodon bleekerianus; Dp: Doryteuthis plei; Lg: Lycengraulis grossidens; Ph: Pellona harroweri; Pp: Peprilus paru; Tl: Trichiurus lepturus, and Xk: Xiphopenaeus kroyeri. * $\mathrm{P}<0.05$.

\begin{tabular}{lcl}
\hline Variables & $F$ & Species relationships (Tukey test) \\
\hline Length & $23.63^{*}$ & $\mathrm{Tl}>\mathrm{Ph}, \mathrm{Dp}, \mathrm{Xk}, \mathrm{Cb}, \mathrm{Lg}, \mathrm{Pp}$ \\
Weight & $19.36^{*}$ & $\mathrm{Tl}>\mathrm{Ph}, \mathrm{Dp}, \mathrm{Xk}, \mathrm{Cb}, \mathrm{Lg}, \mathrm{Pp}$ \\
Protein & $33.7^{*}$ & $\mathrm{Lg}<\mathrm{Tl}, \mathrm{Ph}, \mathrm{Dp}, \mathrm{Xk}, \mathrm{Cb}, \mathrm{Pp} ; \mathrm{Ph}<\mathrm{Tl}, \mathrm{Cb} ; \mathrm{Dp}>\mathrm{Ph}, \mathrm{Pp}, \mathrm{Xk}$ \\
Lipid & $21.2^{*}$ & $\mathrm{Lg}>\mathrm{Tl}, \mathrm{Ph}, \mathrm{Dp}, \mathrm{Xk}, \mathrm{Cb}, \mathrm{Pp} ; \mathrm{Ph}>\mathrm{Cb}$ \\
Ash & $44.8^{*}$ & $\mathrm{Lg}<\mathrm{Tl}, \mathrm{Ph}, \mathrm{Xk}$ Dp $<\mathrm{Tl}, \mathrm{Xk}, \mathrm{Ph}, \mathrm{Pp}, \mathrm{Lg} ; \mathrm{Cb}>\mathrm{Pp}, \mathrm{Dp}, \mathrm{Tl}, \mathrm{Lg} ; \mathrm{Xk}>\mathrm{Tl}, \mathrm{Ph}, \mathrm{Pp}$ \\
Carbohydrate & 1.2 & $\mathrm{Tl} ; \mathrm{Ph} ; \mathrm{Dp} ; \mathrm{Xk}$ Cb; Lg; Pp \\
Caloric value & $19.5^{*}$ & $\mathrm{Lg}<\mathrm{Tl}, \mathrm{Dp}, \mathrm{Ph}, \mathrm{Cb}, \mathrm{Pp} ; \mathrm{Ph}<\mathrm{Cb}, \mathrm{Tl} ; \mathrm{Lg}>\mathrm{Xk} ; \mathrm{Dp}>\mathrm{Ph}, \mathrm{Pp}, \mathrm{Xk}$ \\
\hline
\end{tabular}

specifics in its diet characterizes the cannibalism widely reported in previous studies (e.g. Wojciechowski, 1972; Portsev, 1980; Zhang, 2004; Martins et al., 2005; Bakhoum, 2007; Bittar et al, 2008; Yan et al., 2011). The gregarious behavior of $T$. lepturus, its oral apparatus and voracious feeding behavior (Martins et al., 2005; Froese \& Pauly, 2011) seem to be favoring the cannibalism strategy in this species. Moreover, the high protein and energy content associated with co-specifics, preferred prey of adult specimens (highest IRI), may become the cannibalism energetically advantageous to this predator. The feeding plasticity of this fish, allowing the ingestion of large prey that sometimes reach sizes close to the predator (Bittar et al., 2008), is related to its oral apparatus, composed of a large mouth with developed jaws and teeth, and its digestive tract with an extensible stomach and a long intestine (Figueiredo \& Menezes, 2000).

Previous studies point out that reproductive activity is one of the highest nutritional demands of T. lepturus (Martins et al., 2005; Chiou et al., 2006). The breeding season in $T$. lepturus populations is variable (Martins \& Haimovici, 2000; Al-Nahdi et al., 2009; Yan et al., 2011) and latitude-dependent (Yan et al., 2011). The spawning can be seasonal (Cheng et al., 2001; Chiou et al., 2006; Del Puente \& Chaves, 2009) or occur throughout the year (Martins \& Haimovici, 2000; AlNahdi et al., 2009). In the Oman Sea $\left(\sim 15^{\circ} \mathrm{N}\right)$, Al-Nahdi et al. (2009) reported physiological changes in T. lepturus due to energy demands of spawning. The authors suggested that the available energy as fat and muscle tissue is redirected to maturation of the gonads. In the present study, the adult females' specimens included fish in various maturity stages, but unfortunately it was not possible to access precise data

Table 4. Correlation matrix for proximate-composition ( $\%$ dry mass) and caloric value ( $\mathrm{kcal} \mathrm{g}^{-1}$ dry mass) of all prey species of Trichiurus lepturus in northern Rio de Janeiro State, Brazil. $* \mathrm{P}<0.05$.

\begin{tabular}{lcccc}
\hline & Protein & Lipid & Ash & Carbohydrate \\
\hline Lipid & $-0.67^{*}$ & & & \\
Ash & $0.25^{*}$ & $-0.38^{*}$ & & \\
Carbohydrate & $-0.29^{*}$ & $-0.38^{*}$ & $-0.34^{*}$ & \\
Caloric value & $0.78^{*}$ & $-0.89^{*}$ & 0.01 & $0.37^{*}$ \\
\hline
\end{tabular}

about the ovaries development (see Material and Methods). However, as these specimens were collected during all months (seasons), we could infer about the continuous spawning of this fish species in northern Rio de Janeiro State. The same reproductive pattern was recorded for this species on the southern coast of Brazil $\left(\sim 32^{\circ} \mathrm{S}\right)$ (Martins \& Haimovici, 2000).

The strong correlations between protein and caloric value (positive) and lipid and caloric value (negative) indicated that the predator is attending its energy demand mainly through the prey protein content. In general, fish use protein for growth, but if lipid levels are not sufficient for energy demands, proteins can also be used for this purpose (Wilson, 2002; Hossain et al., 2011). Among the prey species, L. grossidens presented the highest and the lowest lipid and protein contents, respectively. The negative correlation between lipid and caloric value indicated that this was not the preferred source of energy used by the predator in the study region. However, as lipid metabolism is faster in relation to protein (Hossain et al., 2011), ingestion of L. grossidens specimens could be advantageous to the predator when there is need for rapid increase of energy and/or in cases where the energy supply obtained from proteins is not sufficient to its demand.

Probably, the characteristics of T. lepturus adult specimens in relation to voracious feeding behavior, large reproductive period and wide movement along the continental shelf for breeding and feeding activities (Nakamura \& Parin, 1993; Martins \& Haimovici, 1997; Figueiredo \& Menezes, 2000; Kwok \& Ni, 2000; Cheng et al., 2001; Bittar et al., 2008) make necessary the ingestion of high-caloric prey species. The species ontogeny influences its feeding pattern, increasing the feed intensity and the variety of prey consumed by the adult specimens (Martins \& Haimovici, 2000; Martins et al., 2005; Chiou et al., 2006; Yan et al., 2011). Despite the species' high energy needs (Martins et al., 2005; Chiou et al., 2006), the proximate-composition and caloric values of the preferred prey has not yet been described in the literature. In this sense, the data of the present study elucidate the feeding preference of adult females of T. lepturus in relation to nutritional and caloric content of their preferred prey. The species showed food selectivity to prey that provide more energy per biomass, corroborating the hypothesis that adult fish prefer prey with higher caloric value. The feeding events can maximize the predator's caloric gain, which is obtained through a protein-based diet. 


\section{Acknowledgements}

We thank the fishermen from Atafona harbour and technician Silvana R. Gomes, who provided us with the Trichiurus lepturus' prey specimens. We would like to thank Julio C. Voltolini for his comment above statistical analysis. To Instituto Brasileiro do Meio Ambiente e dos Recursos Naturais Renováveis - IBAMA for the permanent license to collect zoological samples (License $n^{\circ}$ 16401-1). VTB received a graduate fellowship from Coordenação de Aperfeiçoamento de Pessoal de Ensino Superior - CAPES and DRA received an undergraduate fellowship from Conselho Nacional de Desenvolvimento Científico e Tecnológico - CNPq. APMB was supported by CNPq (Proc. $n^{\circ}$ 300241/09-7 and n470002/10-7) and Fundação de Amparo à Pesquisa do Estado do Rio de Janeiro - FAPERJ (Proc. $\mathrm{n}^{\circ}$ E-26/103.038/08 and E-26/110.786/10).

\section{Literature Cited}

A. O. A. C. Association of Official Agricultural Chemists. 1984. Official Methods of Analysis. 14 ${ }^{\text {th }}$ Ed. Washington D.C., 1141p. Al-Nahdi, A., A. Al-Marzouqi, E. Al-Rasadi \& J. C. Groeneveld. 2009. The size composition, reproductive biology, age and growth of largehead cutlassfish Trichiurus lepturus Linnaeus from the Arabian Sea coast of Oman. Indian Journal of Fisheries, 56:73-79.

Arnould, J. P. Y., M. M. Nelson, P. D. Nichols \& W. H. Oosthuizen. 2005. Variation in the fatty acid composition of blubber in Cape fur seals (Artocephalus pusillus pusillus) and the implications for dietary interpretation. Journal of Comparative Physiology B: Biochemical, Systemic, and Environmental Physiology, 175: 285-295.

Bakhoum, S. A. 2007. Diet overlap of immigrant narrow-barred Spanish mackerel Scomberomorus commerson (Lac., 1802) and the largehead hairtail ribbonfish Trichiurus lepturus (L., 1758) in the Egyptian Mediterranean coast. Animal Biodiversity and Conservation, 30: 147-160.

Benoit-Bird, K. J. 2004. Prey caloric value and predator energy needs: foraging predictions for wild spinner dolphins. Marine Biology, 145: 435-444.

Bittar, V. T., B. F. L. Castello \& A. P. M. Di Beneditto. 2008. Hábito alimentar do peixe-espada adulto, Trichiurus lepturus, na costa norte do Rio de Janeiro, sudeste do Brasil. Biotemas, 21: 83-90.

Bittar, V. T. \& A. P. M. Di Beneditto. 2009. Diet and potential feeding overlap between Trichiurus lepturus (Osteichthyes: Perciformes) and Pontoporia blainvillei (Mammalia: Cetacea) in northern Rio de Janeiro, Brazil. Zoologia, 26: 374-378.

Cheng, C. H., T. Kawasaki, K. P. Chiang \& C. H. Ho. 2001. Estimated distribution and movement of hair tail Trichiurus lepturus in the Aru Sea, based on the logbook records of trawlers. Fisheries Science, 67: 3-13.

Chiou, W. D., C. Y. Chen, C. M. Wang, \& C. T. Chen. 2006. Food and feeding habits of ribbonfish Trichiurus lepturus in coastal waters of south-western Taiwan. Fisheries Science, 72: 373381.

Clarke, A., P. G. Rodhouse \& D. J. Gore. 1994. Biochemical composition in relation to the energetics of growth and sexual maturation in the ommastrephid squid Illex argentinus.
Philosophical Transactions of the Royal Society of London. Series B, Containing Papers of a Biological Character, 344: 201212.

Cox, M.; E. Gaglione, P. Prowten \& M. Noonan. 1996. Food preferences communicated via symbol discrimination by a California sea lion (Zalophus californianus). Aquatic Mammals, 22: 3-10.

Cunniff, P. A. 1998. Official methods of analysis of AOAC International. Arlington: Association of Official Analytical Chemists. CD-ROM.

Del Puente, S. V. \& P. T. Chaves. 2009. Atividade reprodutiva do peixe-espada, Trichiurus lepturus (Teleostei, Trichiuridae), vulnerável à pesca de pequena escala no extremo-norte do litoral de Santa Catarina, Brasil. Biotemas, 22: 77-84.

Di Beneditto, A. P. M. \& R. M. A. Ramos. 2004. Biology of the marine tucuxi dolphin (Sotalia fluviatilis) in southeastern Brazil. Journal of the Marine Biological Association of the United Kingdom, 84: 1245-1250.

Di Beneditto, A. P. M., R. M. A. Ramos \& N. R. W. Lima. 2001. Sightings of Pontoporia blainvillei (Gervais \& D' Orbigny, 1844) and Sotalia fluviatilis (Gervais, 1853) (Cetacea) in Southeastern Brazil. Brazilian Archives of Biology and Technology, 44: 291296.

Di Beneditto, A. P. M., M. V. B. Santos \& M. V. Vidal Jr. 2009. Comparison between the diet of two dolphins from southeastern Brazil: proximate-composition and caloric value of prey species. Journal of the Marine Biological Association of the United Kingdom, 89: 903-905.

Doyle, T. K., J. D. R. Houghton, R. McDevitt, J. Davenport \& G. C. Hays. 2007. The energy density of jellyfish: estimatives from bom calorimetric and proximate-composition. Journal of Experimental Marine Biology and Ecology, 343: 239-252.

Eder, E. B. \& M. N. Lewis. 2005. Proximate composition and energetic value of demersal and pelagic prey species from the SW Atlantic Ocean. Marine Ecology Progress Series, 291: 4352.

Elliot, M., A. K. Whitfield, I. C. Potter, S. J. M. Blaber, D. P. Cyrus, F. G. Nordlie \& T. D. Harrison. 2007. The guild approach to categorizing estuarine fish assemblages: a global review. Fish and Fisheries, 8: 241-268.

FAO (Food and Agricultural Organization). 2005. Available from: h t t p : / / w w w.f a o.org/figis/s e r v le t/ FiRefServlet?ds=species\&fid=2468. (May 10, 2005 and June 13, 2009).

Figueiredo, J. L. \& N. A. Menezes. 2000. Manual de peixes marinhos do sudeste do Brasil. VI. Teleostei (5). $1^{\text {a }}$ ed. Museu de Zoologia, Universidade de São Paulo, São Paulo, Brasil, 116p.

Folch, J., M. Lees \& S. Stanley. 1957. A simple method for the isolation and purification of total lipids from animal tissues. Journal of Biological Chemistry, 226: 497-509.

Froese, R. \& D. Pauly. Fish Base. Word Wide Web electronic publication. 2010. Available from: www.fishbase.org. version (11/2010), (April/ 2010).

Gauquelin, F., G. Cuzon, G. Gaxiolam, C. Rosas, L. Arena, D. P. Bureau \& J. C. Cochard. 2007. Effect of dietary protein level on growth and energy utilization by Litopenaeus stylirostris under laboratory conditions. Aquaculture, 271: 439-448.

Hair, J. F., R. E. Anderson, R. L. Tatham \& W. C. Black. 1999. Análisis multivariante. Ed. Prentice Hall, Madrid, 832p.

Horwitz, W. 1960. Official methods of analysis of the Association of Official Agricultural Chemists. AOAC, Washington, DC, $832 \mathrm{p}$. 
Hossain, M. A., S. M. Almatar \& C. M. James. 2011. Effect of varying dietary lipid levels and protein to energy (P:E) ratios on growth performance, feed utilization and body composition of sub-adult silver pomfrets, Pampus argenteus (Euphrasen, 1788). Pakistan Journal of Nutrition, 10: 415-423.

Kastelein, R. A., N. Vaughan, S. Walton \& P. R. Wiapkema. 2002. Food intake and body measurements of Atlantic bottlenose dolphins (Tursiops truncatus) in captivity. Marine Environmental Research, 53:199-218.

Kwok, K. Y. \& I. Ni. 2000. Age and growth of cutlassfishes, Trichiurus spp., from the South China. Sea. Fishery Bulletin, 98: 748-758.

Ludwig, J. A. \& J. F. Reynolds. 1988. Statistical Ecology: A primer on methods and computing. John Wiley \& Sons, New York. $337 \mathrm{p}$.

Martins, A. S. \& M. Haimovici. 1997. Distribution, abundance and biological interactions of the cutlassfish Trichiurus lepturus in the southern Brazil subtropical convergence ecosystem. Fisheries Research, 30: 217-227.

Martins, A. S. \& M. Haimovici. 2000. Reproduction of the cutlassfish Trichiurus lepturus in the southern Brazil subtropical convergence ecosystem. Scientia Marina, 64: 97-105.

Martins, A. S., M. Haimovici \& R. Palacios. 2005. Diet and feeding of the cutlassfish Trichiurus lepturus in the Subtropical Convergence Ecosystem of southern Brazil. Journal of the Marine Biological Association of the United Kingdom, 85: 12231229.

Martins, L., J. L. Dominguez \& A. C. P. Bittencourt. 1998. Climatic control of coastal erosion during a sea-level fall episode. Anais da Academia Brasileira de Ciências, 70: 249-266.

Muehe, D. \& E. Valentini. 1998. O litoral do Estado do Rio de Janeiro: uma caracterização físico-ambiental. Fundação de Estudos do Mar, Rio de Janeiro, Brasil. 99p.

Murie, D. J. \& D. M. Lavigne. 1986. Interpetration of otoliths in stomach content analyses of phocid seals: quantifying fish consumption. Canadian Journal of Zoology, 64: 1152-1157.

Nakamura, I. \& N. V. Parin. 1993. FAO Species Catalogue. Vol. 15. Snake mackerels and cutlassfishes of the world (families Gempylidae and Trichiuridae). An annotated and illustrated catalogue of the snake mackerels, snoeks, escolars, gemfishes, sackfishes, domine, oilfish, cutlassfishes, scabbardfishes, hairtails, and frostfishes known to date. FAO Fisheries Synopsis, 125(15): $136 \mathrm{p}$.

Nurnadia, A. A., A. Azrina \& I. Amin. 2011. Proximate composition and energetic value of selected marine fish and shellfish from the West coast of Peninsular Malaysia. International Food Research Journal, 18: 137-148.

Payne, S. A., B. A. Johnson \& R. S. Otto. 1999. Proximate composition of some north-eastern Pacific forage fish species. Fisheries Oceanography, 8: 159-177.
Perez, M. A. 1994. Calorimetry measurements of energy value of some Alaskan fishes and squids. US Department of Commerce, NOAA Technical Memorandum NMFS-AFSC, No. 32, 32p.

Pinkas, L., M. S. Oliphant \& I. L. K. Iverson. 1971. Food habits of albacore, bluefin tuna, and bonito in Californian waters. Department of Fish and Game, Fish Bulletin, 152: 1-105.

Portsev, P. I. 1980. The feeding of cutlass fish, Trichiurus lepturus (Trichiuridae), off the west coast of India. Journal of Ichthyology, 20: 60-65.

Schmidt-Nielsen, K. 1996. Fisiologia Animal: Adaptação e Meio Ambiente. 5 ed. São Paulo: Ed. Santos. 600p.

Spitz, J., E. Mourocq, V. Schoen \& V. Ridoux. Proximate composition and energy content of forage species from the Bay of Biscay: high- or low-quality food? ICES Journal of Marine Science, 67(5): 909-915.

StatSoft, Inc. 2007. STATISTICA (data analysis software system), version 8.0. www.statsoft.com.

Tang, Q., X. Guo, Y. Sun \& B. Zhang. 2007. Ecological conversion efficiency and its influencers in twelve species of fish in the Yellow Sea Ecosystem. Journal of Marine Systems, 67: 282291.

Tierney, M., M. A. Hindell, \& S. Goldsworthy. 2002. Energy content of mesopelagic fish from Macquarie Island. Antarctic Science, 14: 225-230.

Walker, W. A. 1996. Summer feeding habits of Dall's porpoise, Phocoenoides dalli, in the southern Sea of Okhotsk. Marine Mammal Science, 12: 167-181.

Wilson, R. P. 2002. Amino acids and proteins. Pp.143-179. In: Halver, T. E. \& R. W. Hardy (Eds.). Fish Nutrition. 3 Ed. San Diego: Academic Press. 824p.

Winberg, G. G. 1971. Methods for Estimation of Production of Aquatic Animals. London: Academic Press, 175p.

Wojciechowski, J. 1972. Observations on biology of cutlassfish Trichiurus lepturus L. (Trichiuridae) of Mauritania Shelf. Acta Ichthyologica et Piscatoria, 2: 67-75.

Yan, Y., G. Hou, J. Chen, H. Lu \& X. Jin. 2011. Feeding ecology of hairtail Trichiurus margarites and largehead hairtail Trichiurus lepturus in the Beibu Gulf, the South China Sea. Chinese Journal of Oceanology and Limnology, 29: 174-183.

Yan, Y., J. Chen, G. Hou, H. Lu \& X. Jin. 2010. Feeding habits of Trichiurus lepturus in the Beibu Gulf, South China Sea. Chinese Journal of Applied Ecology, 21(3): 749-755. (in Chinese with English abstract).

Zhang, B. 2004. Feeding habits and ontogenetic diet shift of hairtail fish (Trichiurus lepturus) in East China Sea and Yellow Sea. Marine Fisheries Research, 25: 6-12. (in Chinese with English abstract).

Submitted August 22, 2011

Accepted February 13, 2012

Published March 30, 2012 